\title{
Green Banking Practice of Indonesia's Islamic Banks
}

\author{
Rinni Indriyani ${ }^{1}$, Dian Imanina Burhany ${ }^{2}$ and Dwi Suhartanto ${ }^{3}$ \\ Applied Master of Islamic Finance and Banking, Politeknik Negeri Bandung, Indonesia ${ }^{1,2,3}$
}

rinniindriyani27@gmail.com ${ }^{1}$, dianburhany@yahoo.com², dwi.suhartanto@polban.ac.id ${ }^{3}$

\begin{abstract}
The banking sector is increasingly involved in environmental protection and management initiatives by introducing green banking practice. Green banking is very much in line with the principles of Islamic banks that underlie its practice on Islamic values, which among other things prohibit humans from making damage on earth. The purpose of this study is to determine the green banking practice in Indonesia's Islamic Banks from 2014-2017 using environmental risk index. Environmental risk index uses 44 variables which are grouped into ten thematic vectors that relate to different aspects of environmental risk management. This study reveals that the green banking practice in Indonesia's Islamic Banks is still quite low. In average, Indonesia's Islamic Banks excellent in water management, paper management, employee involvement in environmental commitment and collaboration with NGOs while in terms of carbon neutrality, waste management, environmental due diligence, ESG specific funds, environmental training and involvement in initiatives recognized environment still needs improvement. The finding of this study provide a significant contribution in green banking practice of Indonesia's Islamic Banks. They can find out how much green banking practice has so far been running and in what ways they need improvements to achieve the maximum Environmental Risk Index score.
\end{abstract}

Keywords: Green Banking, Islamic Bank, Environmental Risk Index

\section{Introduction}

Carbon intensity has declined substantially in most developing Asian countries over the past decade, with Bangladesh, Indonesia and Vietnam being prominent exceptions [1]. The adverse effects of floods, droughts, storms and heat all over the world today motivate various parties to think seriously in addressing environmental problems. More and more parties, including companies that have been known as profit oriented organization, have begun to show concern and take concrete actions to improve environmental performance. This issue is related to sustainability which consists of economic, social and environmental aspects [2].

Details of the fulfillment of 2015-2019 development funding in the Technocratic Design of the 2015-2019 National Medium Term Development Plan Bappenas [3] states that 71\% of financing for development is carried out by Financial Services Institution and currently 
Financial Services Institutions in Indonesia are dominated by banking sector. Banking sector holds $74 \%$ of the total assets of all financial institutions in Indonesia on June 2016. The dominance of banking assets makes the financial system in Indonesia heavily dependent on banking sector.

Banking sector as a business entity is increasingly involved in environmental protection and management initiatives to reduce carbon emissions and preserve the environment by introducing green banking practice [4]. Although not directly, banking sector contributes to high environmental pollution. The level of energy use (electricity and water), waste disposal and other activities may not have a direct impact, but the external impact of their customer activities is quite large. In Indonesia, the involvement of banking sector in managing environmental and social risks is regulated in Law No. 32 of 2009 concerning Environmental Protection and Management which among other things, regulates the obligation for the industry to protect nature and the environment[5]. This law was then implemented in the OJK Regulation Number 51 / POJK.03 / 2017 concerning the Implementation of Sustainable Finance for Financial Service Institutions, Issuers, and Public Companies [6].

Literature study revealed that several national and international scientists have initiated various studies on green banking ([7]; [8]; [9]; [10]; [11]; [12]; [13]). Green banking is a concept that shows the bank's alignment with the environment. This concept is much in line with the principle of Islamic banks which underlies its practice on Islamic values, which among other things prohibits humans from doing damage on earth. Green banking values which are based on the determination to protect environment are contained in Alqur'an surah Al-Qasas verse 7, Surah Al Baqarah verse 60 and Surah ash-Syuara verse 183. from the survey result of Bank Indonesia regarding green financing carried out by 24 conventional banks and 5 Islamic banks in Indonesia between 2011-2013, found that the portion of green financing in Islamic banks doubled compared to conventional banks [14]. Proposed an environmental risk index (ERI) to show the relationship between "green" and financial performance in financial services companier[15]. ERI provides an overview to financial service companies regarding their environmental performance. This index is in accordance with the business landscape and current regulations of financial services companies. A universal approach to all organizations has been taken in numerical calculations from this index. These variables have been built in such a way as to suit various institutions, from banks and international asset managers to smaller domestic companies.

Based on the assumptions and results obtained from the previous findings, this paper will produce output namely obtaining the value of environmental risk index that describes green banking practice in Indonesia's islamic banks and the average score of vector environment risk index variable to find out the environmental performance excellence of Indonesia's Islamic Banks and where they need area for improvement to overcome the shortcomings that arise.

\section{Method}

The data used is secondary data of annual reports, sustainability reports and additional information from each bank's website. Data were obtained from electronic publications through each bank's website and directly collected from banks that did not publish on the bank's website. Data collected and then cross-checked using primary data collected through questionnaires/interviews with relevant parts of each bank.

Population in this study are all Indonesia's islamic banks registered on Financial Services Authority (OJK) in 2014-2017 with a sample of Indonesia's islamic banks that publish annual report, sustainability report and / or provide corporate social responsibility activities on the company's website from 2014-2017 and are willing to do cross checking data / interviews. The 
population are 13 Islamic Banks, but 1 of them, namely Sharia Aceh Bank is new comer in this industry so that it doesn't fit the period criteria, 2 banks are not willing to cross checking data / interviews. Thus, research sample is 10 Islamic Banks. As requsted by all banks, we do not mention the original name of banks and replace it with initial name.

This study uses Environmental Risk Index (ERI) analyzed using 44 variables grouped into ten thematic vectors related to different aspects of environmental risk management[16]. Summary of variables vectors presented as follow:

Table 1.Variable Vectors Environmental Risk Index

\begin{tabular}{|l|}
\hline $\boldsymbol{V}_{\mathbf{1}}$-Carbon Neutrality \\
\hline $\boldsymbol{V}_{\mathbf{2}}$-Water Management \\
\hline $\boldsymbol{V}_{\mathbf{3}}$-Waste Management \\
\hline $\boldsymbol{V}_{\mathbf{4}}$ - Paper Management \\
\hline $\boldsymbol{V}_{\mathbf{5}}$-Environmental Completion Test \\
\hline $\boldsymbol{V}_{\mathbf{6}}$ - ESG Special Fund \\
\hline $\boldsymbol{V}_{\mathbf{7}}$-Employee Engagement \\
\hline $\boldsymbol{V}_{\mathbf{8}}$-Environmental Training \\
\hline $\boldsymbol{V}_{\mathbf{9}}$ - Collaboration with NGOs \\
\hline $\boldsymbol{V}_{\mathbf{1 0}}$ - Control Variable \\
\hline
\end{tabular}

Analysis method is content analysis that using to obtain ERI score based on information reported by banks in annual report, sustainability report, financial report and/or additional information from each bank's website. To recognize index score of each bank, data from the content analysis then calculated using the following equation:

$E R I=\sum_{n=1}^{10} V n$

Where:

$V_{1}=\sum Z_{i} ; i \epsilon(1, \ldots, 5)$

$V_{2}=\sum Z_{i} ; i \epsilon(6, \ldots, 9)$

$V_{3}=\min \left(\left(W R_{j}+R E C_{j}\right)+\sum Z_{i}, 100\right) ; i \epsilon(10, \ldots, 12)$

$W R_{j}$ - Waste reduction rate, $R E C_{j}$ - Recycling rate

$V_{4}=\sum Z_{i} ; i \epsilon(13, \ldots, 17)$

$V_{5}=\sum Z_{i} ; i \epsilon(18, \ldots, 22)$

$V_{6}=\sum Z_{i} ; i \epsilon(23, \ldots, 29)$

$V_{7}=\min \left(\left(Z_{30}+Z_{31}\right)+\frac{E M_{i, j}+E M_{B, j}}{2}, 100\right.$

$E M_{i, j}$ - Percentage of employees involved in local communities in 2014, 2015, 2016,2017

$E M_{B, j}$ - Percentage of employees participating in the bank's volunteer program in the year 2014,

$2015,2016,2017$

$V_{8}=\sum Z_{i} ; i \epsilon(32, \ldots, 37)$ 
$V_{9}=\sum Z_{i} ; i \in(38, \ldots, 40)$

$V_{10}=\sum Z_{i} ; i \in(41, \ldots, 44)$

Furthermore, data cross-checked by interviewing the relevant parties of banks. Finally, score calculated to get total and average score of all vectors variable, to find out excellence/ superior area in environmental performance of Indonesia's Islamic Banks and where they need improvement.

\section{Result}

3.1 Green Banking Practice at Indonesia's Islamic Banks in 2014-2017

Table 1. Environmental Risk Index (ERI) Indonesia's Islamic Banks in 2014-2017.

\begin{tabular}{|c|c|c|c|c|c|}
\hline \multirow{2}{*}{$\begin{array}{c}\text { Name } \\
\text { Bank }\end{array}$} & \multicolumn{3}{|c|}{ Enviromental Risk Index (ERI) } & \multirow{2}{*}{ Mean } \\
\cline { 2 - 5 } & $\mathbf{2 0 1 4}$ & $\mathbf{2 0 1 5}$ & $\mathbf{2 0 1 6}$ & $\mathbf{2 0 1 7}$ & \\
\hline 1 & 280 & 190 & 250 & 210 & 232.50 \\
\hline 2 & 307 & 403 & 548 & 533 & 447.92 \\
\hline 3 & 415 & 412 & 472 & 472 & 442.50 \\
\hline 4 & 215 & 165 & 190 & 190 & 190.00 \\
\hline 5 & 270 & 280 & 265 & 457 & 317.92 \\
\hline 6 & 185 & 145 & 145 & 145 & 155.00 \\
\hline 7 & 285 & 285 & 285 & 285 & 285.00 \\
\hline 8 & 385 & 385 & 395 & 375 & 385.00 \\
\hline 9 & 277 & 217 & 237 & 277 & 251.67 \\
\hline 10 & 245 & 265 & 412 & 425 & 336.67 \\
\hline Mean & 286.33 & 274.67 & 319.83 & 336.83 & 304.42 \\
\hline
\end{tabular}

Table 1 presents Environmental Risk Index (ERI) which describes green banking practice by Indonesia's Islamic Banks which analyzed using Environmental Risk Index according to [15]. The minimum score for this index is 0 points and the maximum score for this index is 1000 points. From Table 1, it can be seen that mean of Environmental Risk Index (ERI) for all banks from 2014 to 2017 is 304.42 points. Where the highest mean obtained by Bank 2 with score of 447.92 points and the lowest mean obtained by Bank 6 with score of 155 points. Score of 304.42 points from 1000 points means that green banking practice in Indonesia's Islamic Banks is still quite low because the achievement is only $30.4 \%$. In [15], more than 50 percent of banks included in the Global Systemically Important Banks (G-SIB) and international asset managers to smaller domestic companies from various countries showed mean of ERI is 633 points.

Green banking practice in Indonesia's Islamic Banks from 2014 to 2017 increase almost every year. Although in 2015 it decreased from 286.33 points to 274.67 points but in 2016 and 2017 it increase to 319.83 and 336.83. The increase in 2016 and 2017 is possible due to the implementation of several initiatives from OJK to encourage sustainable finance, including the Indonesia First Movers on Sustainable Banking trial, the holding of the Sustainable Finance Award and implementation of International Sustainable Finance Forum (ISFF) in 2016 [3] and the issuance of OJK Regulation Number 51 / POJK.03 / 2017 concerning Implementation of 
Sustainable Finance for Financial Service Institutions, Issuers, and Public Companies in 2017 [6].

\section{Discussion}

\subsection{Excellence and Deficiency of Green Banking Practice in Indonesia's Islamic Banks}

Mean value of all vectors is calculated then analyzed to mark the areas where Indonesia's Islamic Banks excellence in their environmental performance and where they need improvement to overcome emerging shortcomings [15].

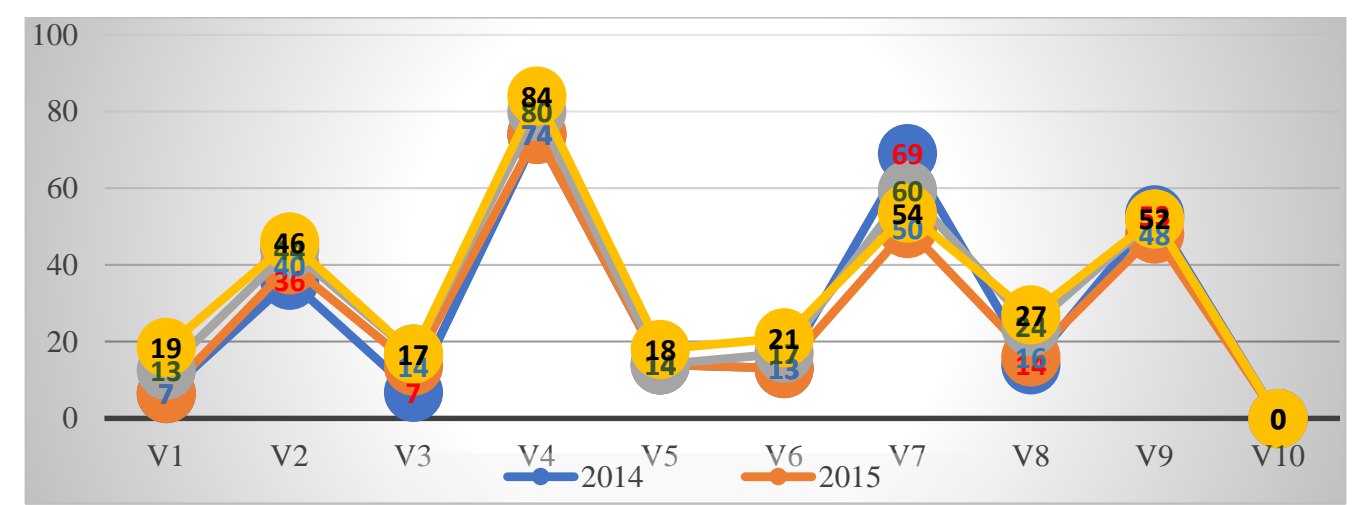

Fig. 1 Average Vector Variables of Indonesia's Islamic Banks for 2014-2017

Figure 1 shows that on average, Indonesia's Islamic Banks in 2014-2017 excellence in water management, paper management, employee involvement in environmental commitment and collaboration with NGOs, showed by highest points. While in terms of carbon neutrality, waste management, environmental due diligence, ESG special funds, environmental training and involvement in recognized environmental initiatives are still needed improvements, showed by lowest points. It can be seen also that from 2014 to 2017 the majority of vectors have increased which means that green banking practice continues to be improved by Indonesia's Islamic Banks.

\section{Conclusion}

Based on the results obtained, this study revealed that green banking practice of Indonesia's Islamic Banks in is still quite low. With an average Environmental Risk Index (ERI) score of 304.42 points from a maximum score of 1000 the achievement of Indonesia's islamic banks is only 30.4\%. On average, Indonesia's islamic banks in 2014-2017 excellent in water management, paper management, employee involvement in environmental commitments and collaboration with NGOs, while in terms of carbon neutrality, waste handling, environmental due diligence, ESG special funds, training environment and involvement in recognized environmental initiatives still need improvement. The findings of this study provide a significant contribution in the application of green banking to Indonesia islamic's banks. Indonesia's islamic banks can find out how much the implementation of green banking has so far been running and in what ways they need improvements to achieve the maximum Environmental Risk Index score. For further research, it is necessary to investigate green banking deeper from secondary data sources so that the possibility of bias when cross checking can be minimized. 


\section{References}

[1] U. Volz, "Fostering Green Finance in Asia," Bonn, 2016.

[2] P. O. Akadiri, E. A. Chinyio, dan P. O. Olomolaiye, "A study of green banking trends in India," Buildings, vol. 2, no. 4, hlm. 126-152, 2012.

[3] OJK, "Kontribusi Industri Jasa Keuangan pada Pembangunan Berkelanjutan," Jakarta, 2016.

[4] K. Shaumya dan A. A. Arulrajah, "The Impact of Green Banking Practices on Banks Environmental Performance: Evidence from Sri Lanka,” J. Finance Bank Manag., vol. 5, no. 1, hlm. 77-90, 2017.

[5] OJK, "Roadmap Keuangan Berkelanjutan di Indonesia Roadmap for Sustainable Finance in Indonesia," Jakarta, 2014.

[6] OJK, Salinan Peraturan Otoritas Jasa Keuangan Nomor 51/POJK.03/2017 tentang Penerapan Keuangan Berkelanjutan Bagi Lembaga Jasa Keuangan, Emiten, dan Perusahaan Publik. Jakarta, 2017, hlm. 1.

[7] M. N. Uddin dan M. Ahmmed, "Islamic Banking and Green Banking for Sustainable Development: Evidence from Bangladesh,” J. Ilmu Ekon. Syariah J. Islam. Econ., vol. 10, no. 101, hlm. 97-114, 2018.

[8] B. C. Chew, L. H. Tan, dan S. R. Hamid, "Qualitative Research in Financial Markets," Qual. Res. Financ. Mark., vol. 8, no. 1, hlm. pp, 2016.

[9] C. B. Suresh dan P. Bhavna, "Green banking in India," J. Econ. Int. Finance, vol. 7, no. 1, hlm. 1-17, 2015.

[10] Muizzuddin, Isnurhadi, dan D. Febrianti, "Green Banking Initiative pada Bank Konvensional dan Syariah di Kota Pelembang," dalam Proceeding Sriwijaya Economic and Busimess Conference, 2015, no. 2009, hlm. 86-94.

[11] M. D. Masukujjaman dan S. Aktar, "Green Banking in Bangladesh: A Commitment towards the Global Initiatives," J. Bus. Technol., vol. VIII, no. 1 and 2, hlm. 17-40, 2013.

[12] S. Bahl, "The role of green banking in sustainable growth," J. Mark. Financ. Serv. ..., vol. 1, no. 2, 2012.

[13] A. Papastergiou dan G. Blanas, "Sustainable Green Banking : The Case of Greece," dalam Management of International Business and Economics s (MIBES) Conference, 2011, hlm. 204-215.

[14] U. Volz, "Towards a Sustainable Financial System in Indonesia," 2015.

[15] L. Prorokowski, "Environmental Risk Index for financial services firms," Qual. Res. Financ. Mark., vol. 8, no. 1, hlm. pp, 2016.

[16] L. Prorokowski, "Environmental Risk Index for Financial Services Firms," dalam Qualitative Research in Financial Markets, vol. 8, 2016, hlm. 10-1108. 